\title{
Maintenance of exercise training benefits is associated with adequate milk and dairy products intake in elderly hypertensive subjects following detraining
}

\author{
A preservação dos benefícios do treinamento físico está associada à ingestão adequada \\ de leite e produtos lácteos em idosos hipertensos após destreino
}

Wilson Max Almeida Monteiro de Moraes ${ }^{1}$, Neucilane Silveira dos Santos², Larissa Pereira Aguiar ${ }^{3}$, Luís Gustavo Oliveira de Sousa ${ }^{4}$

\begin{abstract}
Objective: To investigate whether maintenance of exercise training benefits is associated with adequate milk and dairy products intake in hypertensive elderly subjects after detraining. Methods: Twentyeight elderly hypertensive patients with optimal clinical treatment underwent 16 weeks of multicomponent exercise training program followed by 6 weeks of detraining, and were classified according to milk and dairy products intake as low milk $(<3$ servings) and high milk ( $\geq 3$ servings) groups. Results: After exercise training, there was a significant reduction $(p<0.001)$ in body weight, systolic, diastolic and mean blood pressure, an increase in lower and upper limb strength (chair-stand test and elbow flexor test) as well as in aerobic capacity (stationary gait test) and functional capacity (sit down, stand up, and move around the house) in both groups. However, in the Low Milk Intake Group significant changes were observed: body weight $(+0.5 \%)$, systolic, diastolic and mean blood pressure $(+0.9 \%,+1.4 \%$ and $+1.1 \%$, respectively), lower extremity strength $(-7.0 \%)$, aerobic capacity $(-3.9 \%)$ and functional capacity $(+5.4)$ after detraining. These parameters showed no significant differences between post-detraining and post-training period in High Milk Intake Group. Conclusion: Maintenance of exercise training benefits related to pressure levels, lower extremity strength and aerobic capacity, is associated with adequate milk and dairy products intake in hypertensive elderly subjects following 6 weeks of detraining.
\end{abstract}

Keywords: Hypertension; Exercise; Elderly nutrition; Dairy products

\section{RESUMO}

Objetivo: Investigar se a preservação dos benefícios do treinamento físico está associada à ingestão adequada de leite/produtos lácteos em idosos hipertensos após destreino. Métodos: Vinte e oito idosos hipertensos em tratamento clínico otimizado submetidos a 16 semanas de treinamento físico multicomponente, seguidas por 6 semanas de destreino, foram classificados segundo a ingestão de leite e produtos lácteos como baixo consumo $(<3$ porções/dia) e alto consumo ( $\geq 3$ porções/dia). Resultados: Após o treinamento físico, houve redução significativa $(p<0,001)$ em peso corporal, pressão arterial sistólica, diastólica e média, aumento na força de membros inferiores e superiores (testes sentar-levantar e flexão de cotovelos, respectivamente), capacidade aeróbica (teste da marcha estacionária) e capacidade funcional (sentar, levantar-se e mover-se pela casa) em ambos os grupos. Entretanto, no Grupo Baixo Consumo de Lácteos, observaram-se alterações significativas em peso corporal $(+0,5 \%)$, pressão arterial sistólica, diastólica e média $(+0,9 \%$, $+1,4 \%$ e $+1,1 \%$, respectivamente), força de membros inferiores $(-7,0 \%)$, capacidade aeróbica $(-3,9 \%)$ e capacidade funcional $(+5,4)$ após o destreino. Estes parâmetros não apresentaram diferenças significativas entre o destreino e o período pós-treinamento no Grupo Alto Consumo de Lácteos. Conclusão: A preservação dos benefícios do treinamento físico em relação a pressão arterial, força de membros inferiores e capacidade aeróbia esteve associada com ingestão adequada de leite e produtos lácteos em idosos hipertensos após 6 semanas de destreino.

Descritores: Hipertensão; Exercício; Nutrição do idoso; Laticínios

\footnotetext{
Universidade de Fortaleza, Fortaleza, CE, Brazil.

${ }^{2}$ Universidade Estadual do Ceará, Fortaleza, CE, Brazil.

${ }^{3}$ Faculdade Nordeste - FANOR, Fortaleza, CE, Brazil.

${ }^{4}$ Universidade de São Paulo, São Paulo, SP, Brazil.

Corresponding author: Wilson Max Almeida Monteiro de Moraes - Avenida Washington Soares, 1,321 - Edson Queiroz - Zip code: 60811-341 - Fortaleza, CE - Brazil - Phone: (55 11) 97024-0116 E-mail:wmaxnutrigmail.com

Received on: Mar 7, 2017 - Accepted on: Jul 18, 2017

Conflict of interest: none.

DOI: 10.1590/S1679-45082017A04048
} 


\section{INTRODUCTION}

Cardiovascular diseases (CVD) are the number one cause of death worldwide and systemic arterial hypertension (SAH) is a clinical condition associated with high morbidity and cardiovascular mortality. ${ }^{(1)}$ Systemic arterial hypertension is one of the chronic diseases with higher prevalence in the elderly population and, in Brazil, more than half of them are considered hypertensive. ${ }^{(2)}$

Exercise training (ET) is a well-established nonpharmacological approach to prevent and treat $\mathrm{SAH}$, reducing blood pressure (BP) and associated risk factors, such as obesity, insulin resistance and dyslipidemia. ${ }^{(3)}$ Moreover, multicomponent training (endurance, strength, coordination, balance and flexibility exercises) has shown be able to increase strength levels and attenuate a decline in physical function of older adults. ${ }^{(4-6)}$ However, the beneficial effects of ET may cease or regress when interruption of training periods occur; it is particularly important in older adults because they are more prone to episodes leading to ET interruption, such as severe trauma (e.g., brain injury or complicated fracture), have less adherence to training programs - in such situations, they present lack of training effects. ${ }^{(4)}$ Therefore, strategies to mitigate detraining effects may be interesting to attenuate or prevent the return to pretraining physiological conditions.

Some nutritional strategies, as dairy foods and high milk consumption showed an inverse association with incidence of CVD. ${ }^{(7)}$ One of the possible explanations for the beneficial effects of milk consumption on CVD health is its potential to lower BP, especially in individuals with elevated $\mathrm{BP}^{(8)}$ There is also evidence that milk protein may indirectly improve metabolic health by enhancing lean body mass and skeletal muscle function, which may decrease progressive muscle mass loss, strength and function observed with aging. ${ }^{(9)}$

\section{OBJECTIVE}

To investigate whether maintenance of exercise training effects after 6 weeks of detraining in elderly hypertensive patients is associated with adequate milk and dairy product intake ( $\geq 3$ servings/ day).

\section{METHODS}

\section{Subjects}

Forty-four elderly subjects ( $>60$ years) diagnosed with SAH and seen at a Primary Care Unit in city of Fortaleza, Ceará, Brazil, were recruited to participate in a quasi-experimental study. The objective was to assess the effects of a multicomponent ET program in functional capacity, physical fitness and drop in BP levels. ${ }^{(6)}$ The data were collected between August 2008 and February 2009, in the Centro Comunitário Luiza Távora - Secretariat of Labor and Social Development. All participants received the necessary information about the study and signed a consent form in accordance to National Health Council and Declaration of Helsinki. The research protocol was approved by the Research Ethics Committee of Universidade de Fortaleza (protocol 120/2007, CAAE: 1146.0.000.037-07 and Trial Registration RBR-2xgjh3). The exclusion criteria were: not completing $80 \%$ of all sessions and detraining evaluations; participation in another ET program; relevant calorie-intake restriction, inability to understand the instructions due to cognitive problems; uncontrolled hypertension $(>160 / 100 \mathrm{mmHg})$; chest pain; dizziness or discomfort; bone, muscle or joint problems, or any other previous condition that would preclude participation in the exercise program.

\section{Exercise training and detraining}

The ET program consisted of multi-component sessions twice a week, over a period of 16 weeks; the sessions lasted approximately 60 minutes as previously described.(6) After 16 weeks, the ET program was discontinued for 6 weeks. Of 44 selected subjects, 8 left the ET program and 2 did not achieve $80 \%$ attendance. Hence, 34 patients completed the program; of these, two individuals did not complete detraining evaluations (Figure 1). In order to minimize the possible interfering effect of marked

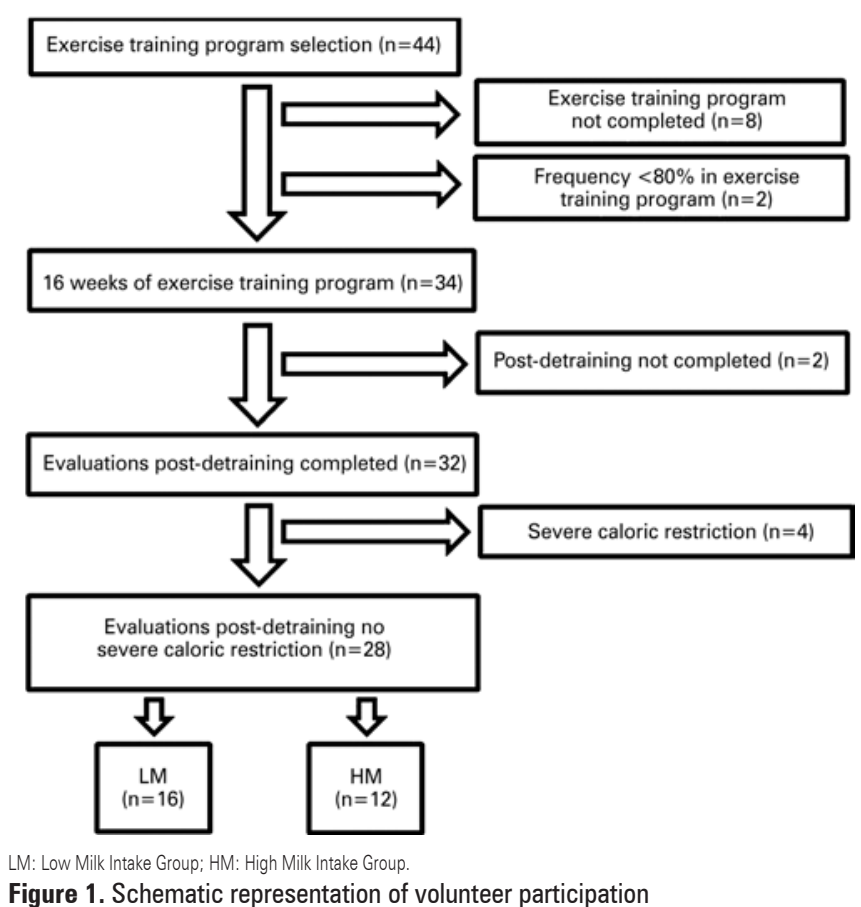


calorie intake restriction, the individuals presenting energy consumption below two standard deviations of the estimated energy expenditure $(n=4)$ were excluded. Thus, 28 individuals were stratified in two groups according to the reported intake of dairy products: the Low Milk Intake Group (LM), comprising those with inadequate milk and dairy product intake ( $<3$ portions/ day) and High Milk Intake Group (HM), for those with milk and dairy products intake in accordance to current recommendations ( $\geq 3$ portions/day) ${ }^{(10)}$ (Figure 1$)$.

Blood pressure levels, body weight and motor tests were measured on three occasions: pre-training, after 16 weeks of training, and after six weeks of detraining. Dietary data were gathered after six weeks of detraining.

\section{Measurements}

For height measurement, a stadiometer (Altura Exata Brazil) with $1 \mathrm{~mm}$ precision was used; and, for body weight, a scale Plenna ${ }^{\circledR}$, with precision of $100 \mathrm{~g}$. Body mass index (BMI) was calculated by the equation body mass $(\mathrm{kg}) /$ height ${ }^{2}\left(\mathrm{~m}^{2}\right)$. Blood glucose, total cholesterol (TC), Low Density Lipoprotein (LDL)-cholesterol and triglycerides levels were obtained from individual registration forms.

The BP measurement was determined with a Missouri ${ }^{\circledR}$ column sphygmomanometer and a Rappaport ${ }^{\circledR}$ stethoscope, with the participant in the sitting position, uncrossed legs, feet flat on the floor. The mean of three measurements taken from the left arm was considered for analysis. ${ }^{(11)}$ The test-retest analysis showed an intrarater correlation coefficient exceeding 0.85 for systolic BP (SBP) and diastolic BP (DBP). ${ }^{(8)}$ The mean BP $(\mathrm{MBP})$ was calculated utilizing the formula: $\mathrm{MBP}=$ $\mathrm{DBP}+(\mathrm{SBP}-\mathrm{DBP}) / 3$.

For aerobic capacity measuring, the stationary gait test was used (SGT), ${ }^{(12)}$ in which the participant initiated knee flexion, simulating gait while standing in place, and the result was the number of steps taken during a 2 minute period.

Lower and upper limb muscle strength was determined by the chair-stand test (CST) and elbow flexor test (EFT), respectively. ${ }^{(12)}$ For CST, the individual started the test sitting a chair with a seat height of $43 \mathrm{~cm}$, arms crossed on the chest. For EFT, the participant sat on a chair, performed elbow flexion and extension cycles holding a dumbbell ( 2 and $4 \mathrm{~kg}$ for women and men, respectively). The results were the total number repetitions performed in 30 seconds.

To assess functional ability, the sit down, stand up, and move around the house test (SSMT) ${ }^{(13)}$ were used. The SSMT consisted of walking around two cones twice alternating turns to the right and to the left. All participants knew the motor tests before performing them.

\section{Dietary data}

A food frequency questionnaire previously developed was used,(14) with local applicability in order to evaluate the energy and nutrient intake. The amounts were recorded in household measures to assist in the conversion of food amount described for grams and portions. The food consumption data were processed with DietWin ${ }^{\circledR}$ software. ${ }^{(15)}$ The calcium, sodium and macronutrients intake was compared to current recommendations. ${ }^{(10,16,17)}$

The estimated energy requirement (EER) was based on equation EER $=662-(9.53 \mathrm{x}$ age $)+[\mathrm{PA} \times(15.91 \mathrm{x}$ weight $+539.6 \mathrm{x}$ height $)]$, in which PA corresponds to physical activity level. ${ }^{(17)}$

\section{Statistical analysis}

Repeated-measures Multivariate Analysis of Variance (MANOVA) was used to examine differences within and between groups over time. Post-hoc comparisons were made with least significant difference test for multiple comparisons, when $\mathrm{p} \leq 0.05$.

In addition, to check if adequate intake of dairy products during detraining could be associated with maintenance of gains observed with ET program, the delta percentage $(\%)$ was calculated using the standard formula: delta $\%=[$ (post-detraining score - post-exercise score)/pretest score]/100.

\section{RESULTS}

The mean age in LM and HM groups was $70.2 \pm 4.9$ and $70.3 \pm 5.0$ years, respectively. The basal values for both groups were, respectively, for BMI $26.2 \pm 2.7 \mathrm{~kg} / \mathrm{m}^{2}$ and $25.5 \pm 2.3 \mathrm{~kg} / \mathrm{m}^{2}$; blood glucose of $109.5 \pm 15.3 \mathrm{mg} / \mathrm{dL}$ and $107.4 \pm 14.6 \mathrm{mg} / \mathrm{dL} ;$ LDL-cholesterol $108.2 \pm 13.7 \mathrm{mg} / \mathrm{dL}$ and $111.7 \pm 10.3 \mathrm{mg} / \mathrm{dL}$; triglycerides of $164.3 \pm 26.4 \mathrm{mg} / \mathrm{dL}$ and $158.2 \pm 24.7 \mathrm{mg} / \mathrm{dL}$. Female participants accounted for $71.4 \%(\mathrm{n}=20)$. The clinical characteristics are presented in table 1 .

In post-detraining period, the mean milk and dairy products intake by the LM group (1.7 portion/day) was significantly lower than that reported by HM group (3.3 portions/day). Likewise, the calcium intake reported by LM group (704mg/day) was lower than the HM group $(1,396 \mathrm{mg} /$ day). Moreover, $100 \%$ of the individuals in HM group consumed calcium above the Recommended Dietary Allowance (RDA) ${ }^{(16)}$ indicating that main source of calcium intake is through the consumption of milk and dairy products. All subjects consumed RDA values for proteins (at least $0.8 \mathrm{~g}$ of protein $/ \mathrm{kg}$ ), ${ }^{(17)}$ and protein intake was not significantly different between the groups $(0.93 \mathrm{~g} / \mathrm{kg}$ in $\mathrm{LM}$ and $1.19 \mathrm{~g} / \mathrm{kg}$ in $\mathrm{HM})$, suggesting that the results were not attributed to total protein intake between the groups. 
Table 1. Baseline clinical characteristics of participants

\begin{tabular}{lcc}
\hline Parameter & $\begin{array}{c}\text { Low Milk } \\
\text { Intake Group } \\
\mathbf{n}(\%)\end{array}$ & $\begin{array}{c}\text { High Milk } \\
\text { Intake Group } \\
\mathbf{n}(\%)\end{array}$ \\
\hline Dyslipidemia & $8(28.6)$ & $6(21.4)$ \\
Overweight* & $7(25)$ & $6(21.4)$ \\
Diabetes mellitus type 2 & $4(14.3)$ & $4(14.3)$ \\
Alcoholism* & $1(3.6)$ & $2(7.1)$ \\
Smokers & $3(10.7)$ & $3(10.7)$ \\
Pharmacological treatment & & \\
ACEls & $11(39.3)$ & $13(46.4)$ \\
Angiotensin II AT1 receptor blockers & $2(7.1)$ & $1(3.6)$ \\
Beta blockers & $3(10.7)$ & $3(10.7)$ \\
Diuretics & $6(21.4)$ & $5(17.9)$ \\
Calcium channel blockers & $1(3.6)$ & $2(3.6)$ \\
Statins & $6(35.7)$ & $4(35.7)$ \\
Aspirin & $1(3.6)$ & $1(3.6)$ \\
Oral hypoglycemic drugs & $6(21.4)$ & $5(17.9)$ \\
\hline * BMl>27kg m2 & &
\end{tabular}

${ }^{*} \mathrm{BMl}>27 \mathrm{~kg} / \mathrm{m}^{2}$

ACEls: angiotensin-converting enzyme inhibitors; AT1: angiotensin receptor.

The energy intake reported in LM and HM were $1594.2 \pm 126.4 \mathrm{kcal}$ and $1628.4 \pm 141.2 \mathrm{kcal}$, respectively, and showed no significant difference between groups ( $\mathrm{p}>0.05)$. The carbohydrate intake amounted to $241.0 \mathrm{~g}$ (56.5\% total energy) in LM and 238.1g in HM (54.7\% total energy). Lipid intake 51.3g (27.1\% total energy) in LM and $49.1 \mathrm{~g}$ ( $24.1 \%$ total energy) in HM ( $\mathrm{p}>0.05)$, and sodium intake reported by LM was $1,637 \mathrm{mg}$ in LM and $1,724 \mathrm{mg}$ in $\mathrm{HM}(\mathrm{p}>0.05)$.

Table 2 shows the results for body mass, BMI, BP levels and motor tests at pre-training, post-training and post-detraining for LM $(n=16)$ and HM $(n=12)$.

Table 2. Body mass, body mass index, blood pressure levels and motor tests during pre-training, post training and post detraining in Low Milk Intake and High Milk Intake groups

\begin{tabular}{|c|c|c|c|c|c|c|}
\hline \multirow{2}{*}{ Parameters } & \multicolumn{2}{|c|}{ Pre-training } & \multicolumn{2}{|c|}{ Post-training } & \multicolumn{2}{|c|}{ Post-detraining } \\
\hline & LM & HM & LM & HM & LM & HM \\
\hline $\mathrm{kg}$ & $70.1 \pm 7.6$ & $68.6 \pm 7.7$ & $69.7 \pm 7.4^{*}$ & $68.0 \pm 6.1^{*}$ & $70.1 \pm 7.5^{* \dagger}$ & $68.1 \pm 6.2^{*}$ \\
\hline BMI, & $26.2 \pm 2.7$ & $25.5 \pm 2.3$ & $=2.7^{*}$ & $25.3 \pm 2.2^{*}$ & $.7^{*+}$ & $25.3 \pm 2.2^{*}$ \\
\hline SBP, $\mathrm{mmHg}$ & $137.6 \pm 3.6$ & $138.3 \pm 4.6$ & $134.7 \pm 4.0^{*}$ & $135.2 \pm 4.5^{*}$ & $135.9 \pm 3.6^{*+}$ & $135.8 \pm 4.7^{*}$ \\
\hline $\mathrm{DBP}, \mathrm{mmHg}$ & $90.1 \pm 4.4$ & $91.3 \pm 5.3$ & $87.5 \pm 4.3^{*}$ & $88.3 \pm 4.9^{*}$ & $88.8 \pm 4.3^{* \dagger}$ & $88.8 \pm 5.0^{*}$ \\
\hline $\mathrm{MBP}, \mathrm{mmHg}$ & $105.9 \pm 3.1$ & $103.7 \pm 5.7$ & $103.2 \pm 3.2^{*}$ & $103.8 \pm 2.8^{*}$ & $104.4 \pm 3.0^{*+}$ & $104.2 \pm 2.9^{*}$ \\
\hline CST, repetitions & $10.3 \pm 2.6$ & $9.6 \pm 2.1$ & $11.2 \pm 2.0^{*}$ & $12.0 \pm 1.8^{*}$ & $10.4 \pm 2.0^{* \dagger}$ & $11.5 \pm 1.2^{*}$ \\
\hline EFT, repetitions & $11.5 \pm 2.4$ & $10.8 \pm 1.6$ & $13.5 \pm 2.1^{*}$ & $13.0 \pm 1.4^{*}$ & $13.2 \pm 1.9^{*}$ & $12.7 \pm 1.3^{*}$ \\
\hline SGT, steps & $71.7 \pm 9.7$ & $72.4 \pm 9.2$ & $78.1 \pm 10.2^{*}$ & $79.5 \pm 8.8^{*}$ & $75.1 \pm 9.7^{*+}$ & $77.8 \pm 8.6^{*}$ \\
\hline SSMT, seconds & $42.1 \pm 6.9$ & $42.0 \pm 8.0$ & $38.2 \pm 5.0^{*}$ & $38.0 \pm 6.3^{*}$ & $40.2 \pm 6.0^{* \dagger}$ & $38.6 \pm 6.4^{*}$ \\
\hline
\end{tabular}

Values expressed as mean \pm standard deviation. ${ }^{*}$ significant difference versus pre-training; $p<0.001 ;{ }^{\dagger}$ significant difference versus post-training, $p<0.001$.

LM: Low Milk Intake Group; HM: High Milk Intake Group; BMI: body mass index; SBP: systolic blood pressure; DBP: diastolic blood pressure; MBP: mean blood pressure; CST: chair-stand test; EFT: elbow flexor test:

SGT: stationary gait test; SSMT: sit down, stand up, and move around the house.
The pre-training values for each variable did not differ between groups. After 16-week ET, there was significant improvement $(\mathrm{p}<0.05)$ in lower and upper extremity strength evaluated by CST and EFT respectively. In both groups the aerobic and functional capacity were better in SGT and SSMT $(\mathrm{p}<0.05)$.

After 6 weeks of detraining, body mass, BMI, BP levels, lower extremity strength, aerobic and functional capacity were worse as compared to post-training period in the LM group, as evidenced by increase in body mass, BMI, SBP, DBP, MBP as well as a drop in CST, SGT and SSMT. However, in HM group, no differences were observed between post-training and post-detraining periods regarding body mass, BMI and BP levels, and in CST, SGT and SSMT. There was no significant relation between changes in motor tests and $\mathrm{BP}$ with baseline body mass or BMI. These data suggest that adequate milk intake can attenuate or reduce loss of benefits brought by ET, such as improved body mass, BP levels, lower extremity strength, aerobic and functional capacity. As to upper limb strength, no significant changes were observed between post-training and post-detraining in both groups, as verified for EFT ( $p>0.05)$.

Since the primary objective of the present study was to investigate the effects of milk and dairy products intake on detraining, the data related to nutritional intake were collected in the post-detraining period. As observed in figure 2, the relative changes that occurred between post-training period and 6 week-detraining were more pronounced in LM Group for all parameters, with exception of EFT results. These data corroborate the findings shown in table 2 , and suggest that adequate milk and dairy products intake can help maintain gains achieved with ET.

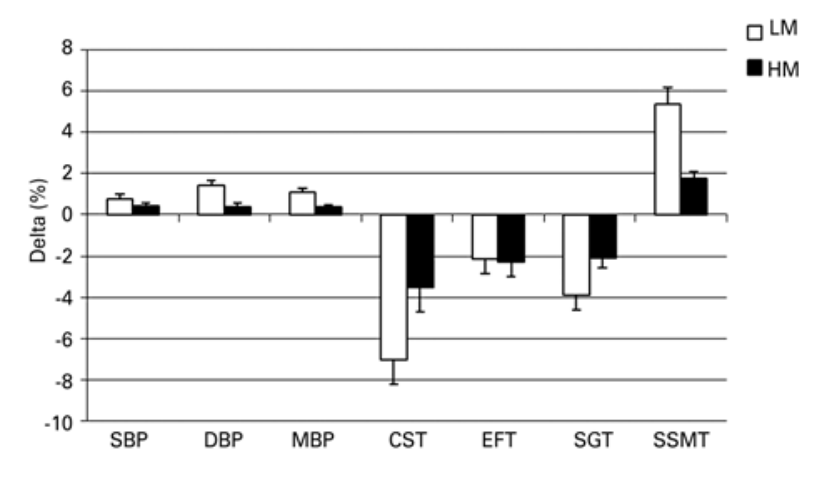

Data are presented as mean \pm standard deviation

LM: Low Milk Intake Group; HM: High Milk Intake Group; SBP: systolic blood pressure; DBP: diastolic blood pressure: MBP: mean blood pressure; EFT: elbow flexor test; SGT: stationary gait test:

SSMT: sit down, stand up, and move around the house.

Figure 2. Relative mean changes in blood pressure levels and motor tests results between post-training period and 6-week detraining and in Low Milk Intake and High Milk Intake groups 


\section{DISCUSSION}

The major finding of this study was that elderly hypertensive subjects were able to maintain gains achieved with 16 weeks of multicomponent training after 6 weeks of detraining, when they consumed milk and dairy products in accordance to the Food Guide for the Brazilian Population. ${ }^{(10)}$ These effects were observed in BP levels, lower limb strength and aerobic and functional capacity. The maintenance of exercise-induced hypotensive effects can help control hypertension and improve muscle strength and aerobic capacity, resulting in less difficulty in carrying out daily activities and better quality of life.

The appropriate intake of dairy products $(\geq 3$ servings/day), in special as part of the Dietary Approaches to Stop Hypertension (DASH) plan, has demonstrated a beneficial role in BP control. ${ }^{(18)}$ The main mechanisms involve the significant contribution for daily requirements of protein and calcium intake, as well as the presence of bioactive peptides. ${ }^{(19)}$ The calcium intake can influence multiple mechanisms involving calcitrophic hormones, vascular reactivity, intracellular calcium levels, as well as interaction with the renin-angiotensin system. ${ }^{(19,20)}$ The bioactive peptides act mainly in renin-angiotensin system, have antioxidant properties and interfere in blood lipids levels. ${ }^{(19)}$

The results of present study corroborate the fact that it is difficult to maintain adequate calcium levels when the milk and dairy products intake is lower than 3 servings/day. ${ }^{(21)}$ This is of particular interest since the mean calcium intake in elderly individuals is $527 \mathrm{mg} /$ day, and approximately $90 \%$ of elderly population in Brazil has calcium intake below RDA values. ${ }^{(22)}$

Moreover, the maintenance of gains related to motor tests in HM group after detraining period suggests some beneficial effect of adequate intake of milk and dairy products on musculoskeletal health. Although the amount of protein ingested is similar between groups, it is known that proteins with high biological value, especially milk-derived proteins, are able to improve single fiber contractile properties by optimization in protein synthesis, resulting in enhanced muscle strength and function. ${ }^{(9)}$

The improvement in mechanical muscle function induced by ET often leads to improved functional capacity in elderly individuals performing activities of daily living. ${ }^{(9)}$ The SSMT emphasizes deambulation, and as an indicator of functional capacity, suggested that HM maintained gains acquired with ET; this was probably influenced by maintenance of gains in lower extremity strength and aerobic capacity. This aspect is of particularly importance since hypertensive elderly patients are 4.2-fold more likely to develop functional limitations than those who are not hypertensive. ${ }^{(23)}$

Unlike what was observed in lower extremity strength, the upper limb strength remained significantly higher after 6 weeks of detraining as compared to pretraining in both groups. These results are corroborated by previous studies of elderly people with same detraining duration and weekly frequency. ${ }^{(4)}$ This suggests that exercise interventions may have a differential impact in distinct muscle groups, probably due to the characteristics of training sessions, with considerable utilization of upper extremities, as well as to the total duration of exercise program, which was longer in our study (16 weeks) in comparison to nine weeks in the investigation by Toraman. ${ }^{(4)}$

It is estimated that 20 to $25 \%$ of hypertensive individuals do not present lower BP levels after exercising. This heterogeneity of individual response to the antihypertensive effects of exercise is mostly attributed to genetic components and polymorphisms. ${ }^{(24)}$ However, the genetic components are not enough to explain this variance, and there is evidence suggesting that ingestion of nutrients and dietary components may contribute to this heterogeneous response to exercise. ${ }^{(20)}$ In the present study, the influence of milk products intake on BP levels could also be observed in detraining periods. Thus, dietary components should be further investigated regarding their possible interference in the antihypertensive responses to exercise.

The limitations of our study should be acknowledged. Since the data related to nutritional intake were collected in post-detraining period only, we cannot ensure that individuals maintained the same dietary habits during all ET training and detraining period. Future studies might consider data collection related to diet intake more frequently, with a more rigid control in variables interfering in BP levels.

\section{CONCLUSION}

In summary, we provide evidence that maintenance of exercise training benefits is associated with adequate milk and dairy products intake ( $\geq 3$ servings/day) in elderly hypertensive, reducing the increase in blood pressure levels and loss of lower limb strength and aerobic capacity, which results in better maintenance of functional capacity after six weeks of detraining.

\section{ACKNOWLEDGEMENTS}

To Roseclea Barbosa, Pamella Ramona and to Emílio Praxedes, for their assistance in data collection. 


\section{REFERENCES}

1. Writing Group Members, Mozaffarian D, Benjamin EJ, Go AS, Arnett DK, Blaha MJ, Cushman M, Das SR, de Ferranti S, Després JP, Fullerton HJ, Howard VJ, Huffman MD, Isasi CR, Jiménez MC, Judd SE, Kissela BM, Lichtman JH, Lisabeth LD, Liu S, Mackey RH, Magid DJ, McGuire DK, Mohler ER 3rd, Moy CS, Muntner P, Mussolino ME, Nasir K, Neumar RW, Nichol G, Palaniappan L, Pandey DK, Reeves MJ, Rodriguez CJ, Rosamond W, Sorlie PD, Stein J, Towfighi A, Turan TN, Virani SS, Woo D, Yeh RW, Turner MB; American Heart Association Statistics Committee; Stroke Statistics Subcommittee. Executive Summary: heart disease and stroke statistics--2016 Update: a report from the American Heart Association. Circulation. 2016;133(4):447-54.

2. Brasil. Ministério da Saúde. Secretaria de Vigilância em Saúde. Departamento de Vigilância de Doenças e Agravos não Transmissíveis e Promoção da Saúde. Vigitel Brasil 2014: vigilância de fatores de risco e proteção para doenças crônicas por inquérito telefônico [Internet]. Brasília (DF): Ministério da Saúde; 2015 [citado 2017 Set 8]. Disponível em: http://bvsms.saude.gov. br/bvs/publicacoes/vigitel brasil 2014.pdf

3. Pescatello LS, MacDonald HV, Lamberti L, Johnson BT. Exercise for hypertension: a prescription update integrating existing recommendations with emerging research. Curr Hypertens Rep. 2015;17(11):87. Review.

4. Toraman NF, Ayceman N. Effects of six weeks of detraining on retention of functional fitness of old people after nine weeks of multicomponent training. Br J Sports Med. 2005;39(8):565-8; discussion 568.

5. Carvalho MJ, Marques E, Mota J. Training and detraining effects on functional fitness after a multicomponent training in older women. Gerontology. 2009; 55(1):41-8.

6. Moraes WM, Souza PR, Pinheiro MH, Irigoyen MC, Medeiros A, Koike MK. Exercise training program based on minimum weekly frequencies: effects on blood pressure and physical fitness in elderly hypertensive patients. Rev Bras Fisioter. 2012;16(2):114-21.

7. Fekete ÁA, Givens DI, Lovegrove JA. The impact of milk proteins and peptides on blood pressure and vascular function: a review of evidence from human intervention studies. Nutr Res Rev. 2013;26(2):177-90. Review.

8. Hidayat K, Du HZ, Yang J, Chen GC, Zhang Z, Li ZN, et al. Effects of milk proteins on blood pressure: a meta-analysis of randomized control trials. Hypertens Res. 2017;40(3):264-70.

9. McGregor RA, Poppitt SD. Milk protein for improved metabolic health: a review of the evidence. Nutr Metab (Lond). 2013;10(1):46.

10. Brazil. Ministry of Health of Brazil. Secretariat of Health Care. Primary Health Care Department. Dietary Guidelines for the Brazilian population [Internet]. 2a ed. Brasilia (DF): Ministry of Health of Brazil; 2014 [cited 2017 Mai 18]. Available from: http://189.28.128.100/dab/docs/portaldab/publicacoes/guia alimentar_populacao_ingles.pdf

11. Chobanian AV, Bakris GL, Black HR, Cushman WC, Green LA, Izzo JL Jr, Jones DW, Materson BJ, Oparil S, Wright JT Jr, Roccella EJ; Joint National
Committee on Prevention, Detection, Evaluation, and Treatment of High Blood Pressure. National Heart, Lung, and Blood Institute; National High Blood Pressure Education Program Coordinating Committee. Seventh report of the Joint National Committee on Prevention, Detection, evaluation, and treatment of high blood pressure. Hypertension. 2003;42(6):1206-52.

12. Rikli RE, Jones CJ. Development and validation of a functional fitness test for community residing older adults. J Aging Phys Act. 1999;7(2):129-61.

13. Andreotti RA, Okuma SS. Validação de uma bateria de testes de atividades da vida diária para idosos fisicamente independentes. Rev Paul Educ Fís. 1999;13(1):46-66.

14. Henriques EM. Development, testing and validation of a questionnaire of food frequency and physical activity in low-income women [dissertation]. Fortaleza: Ceara State University; 2001.

15. Software of nutritional evaluation. DietWin Clinico [computer program]. Version 3.0. Porto Alegre (RS): Brubins Comércio de Alimentos e Supergelados; 2002.

16. Institute of Medicine (US) Standing Committee on the Scientific Evaluation of Dietary Reference Intakes. Dietary reference intakes for calcium, phosphorus, magnesium, vitamin $\mathrm{d}$, and fluoride. Washington (DC): National Academies Press (US); 1997.

17. Trumbo P, Schlicker S, Yates AA, Poos M; Food and Nutrition Board of the Institute of Medicine, The National Academies. Dietary reference intakes for energy, carbohydrate, fiber, fat, fatty acids, cholesterol, protein and amino acids. J Am Diet Assoc. 2002;102(11):1621-30. Erratum in: J Am Diet Assoc. 2003;103(5):563.

18. Kris-Etherton PM, Grieger JA, Hilpert KF, West SG. Milk products, dietary patterns and blood pressure management. J Am Coll Nutr. 2009;28 Suppl 1:103S-19S. Review.

19. Chrysant SG, Chrysant GS. An update on the cardiovascular pleiotropic effects of milk and milk products. J Clin Hypertens (Greenwich). 2013;15(7):503-10. Review.

20. Pescatello LS, Turner D, Rodriguez N, Blanchard BE, Tsongalis GJ, Maresh CM, et al. Dietary calcium intake and renin angiotensin system polymorphisms alter the blood pressure response to aerobic exercise: a randomized control design. Nutr Metab (Lond). 2007;4:1.

21. Weaver CM, Heaney RP, editors. Calcium in human health. New York: Humana Press; 2006. Food sources, supplements, and bioavailabity. p. 129-42.

22. Instituto Brasileiro de Geografia e Estatística (IBGE). Pesquisa de Orçamentos Familiares 2008-2009. Aquisição alimentar domiciliar per capita. Brasil e grandes regiões [Internet]. Rio de Janeiro: IBGE; 2010 [citado 2017 Maio 19]. Available from: http://biblioteca.ibge.gov.br/visualizacao/livros/liv47307.pdf

23. Alves LC, Quinet Leimann BC, López Vasconcelos ME, Sá Carvalho M, Godoi Vasconcelos AG, Oliveira da Fonseca TC, et al. [The effect of chronic diseases on functional status of the elderly living in the city of São Paulo, Brazil]. Cad Saude Publica. 2007;23(8):1924-30. Portuguese.

24. Roth SM. Perspective on the future use of genomics in exercise prescription. J Appl Physiol (1985). 2008;104(4):1243-5. 